San Jose State University

From the SelectedWorks of Christine Hagar

2003

Sharing indigenous knowledge: To share or not to share? That is the question

Christine Hagar, University of Illinois at Urbana-Champaign 


\author{
Chris Hagar \\ Graduate School of Library \& Information Science \\ University of Illinois at Urbana-Champaign
}

\title{
Sharing indigenous knowledge: To share or not to share? That is the question
}

\begin{abstract}
The Internet and digital technology create new possibilities for the development of cultures, communities and knowledge. Over the last twenty years there has been a great increase in interest in indigenous knowledge from a variety of groups, including academia, development agencies and the corporate world. Within this diverse range of interests, there have been initiatives to facilitate a global network to exchange indigenous knowledge by development agencies such as the World Bank's 'Indigneous Knowledge for Development Program' and UNESCO's 'Best Practices of Indigenous Knowledge' database. The development agencies appear to be mainly concerned with systematizing indigenous knowledge and looking at the notion of indigenous knowledge as forming part of global knowledge which can be preserved, transferred, or adopted and adapted elsewhere. Multilateral and bilateral donors have also facilitated the establishment of national indigenous knowledge resource centers which are organizational structures through which indigenous knowledge is recorded, stored, screened for potential economic uses at the national level, and distributed to other centers in appropriate ways.
\end{abstract}

I argue that it is necessary to abandon the assumption that we can record and document indigenous knowledge and pass it 'up' to interested parties as technological packages are passed 'down' to beneficiaries. Indigenous knowledge systems are rarely if ever isolated from the rest of the world; people will incorporate and reinterpret aspects of western knowledge and practice into their traditions as part of the ongoing process of globalization. Meanwhile, in the commercial arena, national and multinational corporations have taken indigenous knowledge as a valuable commodity and are 'sharing' the knowledge in the commercial world for profit. Within the framework of social capital, I explore the sharing of indigenous knowledge at the local level and at the global level. I argue that the embeddedness and contextual nature of indigenous knowledge creates tensions for sharing it on a global scale. I also argue that although there is a strong public purpose interest in greater community access and sharing of indigenous knowledge, there should be mechanisms for the compensation of indigenous peoples for the commercial use of their knowledge - indigenous knowledge should be treated as a form of intellectual property in order to increase the economic return from resources maintained by indigenous peoples. Once indigenous communities are connected to the Internet, their opportunities for benefiting economically are being marginalized.

Résumé: Internet et les technologies numériques créent de nouvelles possibilités pour le développement des cultures, des communautés et des connaissances. Au cours des vingt dernières années, il y a eu une recrudescence de l'intérêt démontré par plusieurs groupes, y compris le monde universitaire, les agences de développement et le milieu des affaires, pour les connaissances autochtones. Parmi ces intérêts nouveaux, certaines initiatives ont été entreprises pour faciliter la création d'un réseau mondial permettant l'échange des connaissances autochtones par les agences de développement tel que le «Programme Connaissances Autochtones pour le Développement" de la Banque Mondiale et la base de données «Best Practices of Indigenous Knowledge » de l'Unesco. Le principal sujet de préoccupation des agences de développement est la systématisation des connaissances autochtones et l'examen du fait que les connaissances autochtones sont une partie intégrante des connaissances mondiales devant être préservées, 
transmises, adoptées ou adaptées partout dans le monde. Des donateurs bilatéraux et multilatéraux ont également facilité l'établissement de centres nationaux de ressources des connaissances autochtones qui sont des structures organisationnelles grâce auxquelles les connaissances autochtones sont enregistrées, préservées, sélectionnées pour leur utilisation économique potentielle au niveau national et distribuées dans d'autres centres de façon appropriée.

Je considère qu'il est nécessaire d'abandonner l'hypothèse qu'il est impossible d'enregistrer et documenter les connaissances autochtones et de les transmettre aux parties intéressées comme sont transférées les connaissances technologiques habituelles. Les systèmes de connaissances autochtones sont rarement séparés, sinon jamais, du reste du monde. Les individus incorporeront et réinterpréteront les différents aspects des connaissances et coutumes occidentales selon leurs traditions comme conséquence du processus de globalisation. Pendant ce temps, sur la scène commerciale, les organismes nationaux et internationaux considèrent de plus en plus les connaissances autochtones comme des marchandises de valeur et commercialisent ces connaissances avec profits. À l'intérieur de la structure du capital social, j'examine le partage des connaissances autochtones au niveau local et international. Je maintiens que l'incorporation et la nature contextuelle des connaissances autochtones créent des tensions lors de leur partage au niveau mondial. Je souligne également que, malgré le fait qu'il existe un grand intérêt public pour l'accès et le partage de ces connaissances autochtones, il doit également y avoir des mécanismes compensatoires pour les communautés autochtones lors de l'utilisation commerciale de leurs connaissances. Les connaissances autochtones doivent être considérées comme une forme de pauvreté intellectuelle, de manière à augmenter le rendement économique de ces ressources sauvegardées par les peuples autochtones. Une fois que les communautés autochtones seront branchées à Internet, leurs possibilités de bénéfices financiers diminueront.

\section{INTRODUCTION}

The use of the term "indigenous " began at the Institute of Development Studies (IDS), University of Sussex, UK, in 1979. A special issue of the IDS Bulletin featured the term "indigenous technical knowledge", and it was followed by the publication of Indigenous Knowledge Systems and Development (Brokensha, Warren and Werner, 1980). Over the last twenty years there has been a great increase in interest in indigenous knowledge from a variety of groups, including academia, development agencies and the corporate world. Within this diverse range of interests, there have been initiatives to share indigenous knowledge on a global scale by development agencies such as the World Bank's 'Indigneous Knowledge for Development Program (World Bank, 2002) and UNESCO's 'Best Practices of Indigenous Knowledge' (UNESCO, 2002) database. Meanwhile, national and multinational corporations have taken indigenous knowledge as a valuable commodity and are 'sharing' the knowledge in the commercial world for profit.

In this paper, I will examine the concept of indigenous knowledge and discuss why there has been an indigenous knowledge 'revolution'. Within the framework of social capital, I will explore the sharing of indigenous knowledge at the local level and at the global level. I will argue that the embeddedness and contextual nature of indigenous knowledge creates tensions for sharing it on a global scale. I will also argue that although there is a strong public purpose interest in greater community access and sharing of indigenous knowledge, there should be mechanisms for the compensation of indigenous peoples for the commercial use of their 
knowledge - indigenous knowledge should be treated as a form of intellectual property in order to increase the economic return from resources maintained by indigenous peoples.

Some of the key questions that I will address are: who shares indigenous knowledge? how is indigenous knowledge shared? for what purposes is indigenous knowledge shared? how should indigenous knowledge be protected? can indigenous knowledge be codified for use in other situations? To begin, I will discuss the different ways of interpreting indigenous knowledge and how I define the concept.

\section{WHAT IS INDIGENOUS KNOWLEDGE?}

In reviewing the literature, what is meant by indigenous knowledge is by no means clear.

The term indigenous knowledge, indigenous technical knowledge, local knowledge, traditional knowledge, folk knowledge are used interchangeably. It can be argued that there is a distinction between indigenous and traditional knowledge, that true tradition comprises proven ancient, original and distinctive customs, conventions and routines; thus tradition operates on the practical level of repeated actions based on opinion or belief. As Brouwer (1993) suggests the actors need not have any knowledge, indigenous or otherwise, to successfully carry out and pass on their traditions.

However, I agree with Ellen and Harris (1996) that there is arguably enough overlap between the meanings of these labels to recognize the existence of a shared intersubjective understanding, some 'epistemic community'. The Indigenous Knowledge and Development Monitor editorial mentions three definitions to be used in its publication which are useful to consider. The first definition agrees that 'indigenous knowledge' is used synonymously with 'traditional' and 'local' knowledge: "knowledge that is unique to a given culture or society. Indigenous knowledge contrasts with the international knowledge system generated by universities, research institutions and private firms. It refers to the knowledge of indigenous peoples as well as any other defined community. It is the basis for local-level decision making in agriculture, health care, food preparation, education, natural-resource management, and a host of other activities in rural communities (Warren, 1991)".

The second definition given in the Indigenous Knowledge and Development Monitor editorial is "the unique, traditional, local knowledge existing within and developed around the specific conditions of women and men indigenous to a particular geographic area"(Grenier, 1998) and the third is based on Grenier's definition with a few alterations: "Indigenous knowledge is the sum total of the knowledge and skills which people in a particular geographic area possess, and which enable them to get the most out of their natural environment. Most of this knowledge and these skills have been passed down from earlier generations, but individual men and women in each new generation adapt and add to this body of knowledge in a constant adjustment to changing circumstances and environmental conditions. They in turn pass on the body of knowledge intact to the next generation, in an effort to provide them with survival strategies".

In the literature some of the commonly asserted characteristics of indigenous knowledge are: it is generated within communities; it is location and culture specific; it is the basis for decision 
making and survival strategies; it is not systematically documented, it covers critical issues: primary production, human and animal life, natural resources management; it is dynamic and based on innovation, adaptation, and experimentation and it is oral and rural in nature (Ellen and Harris, 1998). I would suggest that indigenous knowledge covers more than the critical issues listed and also that indigenous knowledge can also be urban as well as being rural in nature.

I see that there are major problems in interpreting what passes for indigenous knowledge and I would emphasize the importance of recognizing the embeddedness or contextual nature of customary thought and practice. What happens in practice is that scientific or technical knowledge is used as a means to differentiate between "useful" or "correct" indigenous knowledge and "useless" or "incorrect" indigenous knowledge (Silitoe, 1998) Thus much of what could be seen as indigenous knowledge is related to "superstition" or symbolism" and marginalized in many discussions.

I would argue that indigenous knowledge is a contested concept. Indigenous knowledge here is the knowledge of an "other" who becomes defined in opposition to an authoritative "we", vaguely presented as scientists from the West (Ellen and Harris 1996). The tendency to define indigenous knowledge in relation to western knowledge is problematic in that it raises western science to a level of reference, ignoring the fact that all systems are culture-bound, and thereby excluding western knowledge itself from analysis.

My definition of indigenous knowledge for the purposes of this paper is the systematic information that remains in the informal sector, usually unwritten, often preserved in oral tradition and is culture specific. There is a tendency to assume that all knowledge worth having is encoded verbally and can be articulated by local people. Increasingly it is clear that much practical indigenous knowledge is not stored in this way but it is absorbed by doing, watching, and living a particular way of life (Posey, 1998) - I include this in my definition.

An important point to conclude this section, is that it is impossible to use indigenous in any morally neutral or apolitical way, as peoples identify themselves as indigenous to establish rights and to protect their interests. The study of indigenous knowledge is challenging not only because of difficulties in cross-cultural communication and understanding but also because of their inevitable political dimensions (Silitoe, 1998).

This is one of the reasons why indigenous knowledge has seen an increase in interest; the next section discusses this further.

\section{THE HISTORY AND THE REVOLUTION}

The role of nineteenth century colonialism and social science in ignoring and sometimes maligning indigenous knowledge has been well documented (Warren,1989). Even when the knowledge was clearly being utilized, it was often redescribed in ways that eliminated any credit to those who had brought it to the attention of science in the first place.

In tracing the history of indigenous knowledge, the knowledge and skill base in ethnocentric societies were vertically transmitted and confined within families. The transfer of knowledge 
within communities was mostly executed through "training on the job" and subsequently generations introduced fresh innovations based on emerging needs or discovery of raw materials. The main driver of innovation was better utilization of natural resources and community survival (Ganguli, 2000). The protection of community knowledge as understood in today's concepts of "intellectual property rights" was not considered a necessity.

The oral and 'powerless' nature of indigenous knowledge has made it largely invisible to the development community and to global science. As a consequence, indigenous knowledge has not been captured and stored in a systematic way, with the implicit danger that it may become extinct. This situation has changed and there has been an explosive growth in the number of publications about the relevance of indigenous knowledge in a variety of policy sectors (NUFFIC, 2002). Studies that depicted local communities and their knowledge as primitive, simple and static are now countered by discussions that describe the complexity and sophistication of many indigenous knowledge management systems.

Over the last twenty years the process of marginalizing indigenous knowledge has been reversed. Silitoe (1998) refers to a revolution in indigenous knowledge; an increase in interest in the academic world, a greater role has been given to indigenous knowledge by governments, development agencies, non-government agencies and also increased interest from the corporate world. Others argue that if there is a revolution in indigenous knowledge then it has come from advances in international human rights and recognition of indigenous and traditional peoples in international law.

Traditionally most of the academic contributors in indigenous knowledge were geographers and anthropologists. Now a broader academic interest is represented in the indigenous knowledge debate including the disciplines of agriculture, horticulture, botany zoology, forestry ecology, animal science, soil science, medicine and pharmacology.

One of the reasons for the increase in cross-disciplinary interest and communication is the vision in the academic world that indigenous knowledge could contribute to a better understanding of sustainable development in all its ecological and cultural complexity, and therefore had a role to play in the global knowledge system and in participatory approaches to development (Brouwer, 1993).

Governments, bilateral and multilateral development organizations are interested in ways in which indigenous knowledge can contribute to the development process. Several international development agencies introduced a reorientation in policy on the basis of Agenda 21, the global program of action adopted at the Earth Summit in Rio de Janeiro (Brazil) in June 1992. These institutions are looking for concrete examples and cases that indicate the added value of indigenous knowledge to the impact and sustainability of development interventions. Examples of this are the World Bank's (2002) initiative on "Indigenous Knowledge for Development" and the UNESCO (2002) MOST database of 'Best Practices in Indigenous Knowledge'. Non government organizations have become significant 'knowledge making' institutions and within the "universalizing discourse " of environmentalism, indigenous knowledge has become reified. (Ellen and Harris, 1996). 
Within the corporate world, national and multinational companies, are what Robert Chambers describes as 'mining' indigenous knowledge, commodifying indigenous knowledge which is being patented and copyrighted for profit by multinational organizations.

Just as there has been a greater interest shown in indigenous knowledge, so there has been a rise to prominence in the 1990s, across all of the social science disciplines in the idea of the notion of social capital. In the following section, I will discuss this notion of social capital in the context of the development world.

\section{SOCIAL CAPITAL, THE DEVELOPMENT PARADIGM AND INDIGENOUS KNOWLEDGE}

The appeal of the theory of social capital is that it brings together under one rubric the disciplines of development theory, social development, economics, political science, and sociology. It brings together the functioning of markets, government, and social development into a single framework (Kilby, 2002). In the social development paradigm indigenous knowledge has more value than other forms of 'capital'; it is a key element of the social capital of the poor and widely recognized as one of the few sources of capital available to them. Traditional peoples have applied their social capital in developing, securing, exploiting, and managing unique resources. The pursuit and cultivation of local knowledge is an important feature of social capital.

Most scholars attribute the modern use of social capital to Bourdieu (1986), who defines it as "the aggregate of the actual or potential resources which are linked to possession of a durable network of more or less institutionalized relationships of mutual acquaintance and recognition or in other words, to a membership in a group - which provides each of its members with the backing of the collectively-owned capital". Later, the notion of social capital was popularized by Robert Putman's work on the making of democracy in modern Italy (Putnam, 1993) and since then the development community has become increasingly enthusiastic about the potential use of the concept. Putnam's narrow definition of social capital is as a set of "horizontal associations" between people; social capital consists of social networks and associated norms that have an effect on the productivity of the community. The key feature of social capital in this definition is that it facilitates coordination and cooperation for the mutual benefit of the members of the association.

For the purposes of this paper, I will use the straightforward and simple definition - social capital as the norms and networks that enable people to act collectively, as used by Woolcock and Narayan (2000). This definition allows the focus to be the sources of social capital, as opposed to the consequences (Portes, 1998) while recognizing that important features of social capital, such as trust and reciprocity, are developed in an iterative process. Second this definition allows us to incorporate different dimensions of social capital, and to recognize that communities can have access to more or less of them. The poor, for example may have a close-knit and intensive stock of "bonding" social capital that they leverage to "get by" (Briggs, 1998), but be lacking in the more diffuse and extensive"bridging" social capital deployed by the non-poor to "get ahead". Third, while this definition presents the community as the primary unit of analysis, it allows for the fact that social capital nonetheless can be appropriated by individuals and households, and 
that how communities themselves are structured turns in large part on their relationship with the state (Woolcock and Narayan, 2000), important in the development paradigm. I will draw on these dimensions of social capital in my discussion of the sharing of local indigenous knowledge on a global scale.

\section{FROM LOCAL TO GLOBAL}

In this section, I will explore initiatives by development agencies to share local indigenous knowledge on a global scale, focusing on the World Bank who is facilitating a global network to exchange indigenous knowledge.

Development agencies have been for some time reviewing the role of indigenous knowledge in the development process at the policy level and now consider indigenous knowledge as an invaluable and under-utilized knowledge reservoir, which presents developing countries with a powerful asset. I agree with Gorjestani (2000) that there are a number of roles for development agencies at the local level. These include enabling communities to use their indigneous knowledge; to empower the indigenous communities by enabling them to shape their own development agenda by actively participating in the development dialogue, determining research agendas, transforming / enhancing good governance, integrating indigenous knowledge in development; access - helping local practitioners and communities to exchange knowledge of local practices, build local knowledge networks, engage authorities, researchers and experts, dialogue with development partners, leverage local and global knowledge and to give indigenous peoples appropriate technology that can help to enable and empower local practitioners to improve the quality of life.

The development agencies appear to be mainly concerned with systematizing indigenous knowledge and looking at the notion of indigenous knowledge as forming part of global knowledge which can be preserved, transferred, or adopted and adapted elsewhere. As an example of this the objectives of the World Bank Indigenous Knowledge Program (World Bank, 2002) include - enabling the development community to learn more about the indigenous / traditional practices in local communities so as to better adapt global knowledge to local conditions, developing pilot instruments for the capture, dissemination, and application of indigenous / traditional knowledge practices and to facilitate the sharing of indigenous practices and innovations among local communities through a South-to- South exchange.

Multilateral and bilateral donors have also facilitated the establishment of national indigenous knowledge resource centers which are organizational structures through which indigenous knowledge is recorded, stored, screened for potential economic uses at the national level, and distributed to other centers in appropriate ways. This interest in systematizing indigenous knowledge arose about ten years ago when an influential policy document by the National Research Council (1992) stated that "development agencies should place greater emphasis on, and assume a stronger role in, systematizing the local knowledge base - indigenous knowledge. This document warned that indigenous knowledge is being lost at an unprecedented rate, and that its documentation should be a research priority. It advocated that indigenous knowledge and its preservation, preferably in database form should take place as quickly as possible. 
Many experts contend that indigenous knowledge can be systematized, stored, manipulated, and made intelligible to others independent of the historical and spatial context in which it was produced - a contention that a number of critiques are challenging. I see the danger of turning local knowledge into global knowledge is that 'at the empirical level all indigenous knowledge is relative and parochial, no two societies perceive or act upon the environment in the same ways. It is the local embeddedness of indigenous knowledge that has made it successful. Indigenous knowledge is tacit knowledge and therefore difficult to codify, it is embedded in community practices, institutions, relationships and rituals. Development professionals have contextualized and scientized indigenous knowledge by codifying it and rejecting the cultural context.

I agree with McCall (1995) that it is necessary to abandon the assumption that we can record and document indigenous knowledge and pass it 'up' to interested parties as technological packages are passed 'down' to beneficiaries. Indigenous knowledge systems are rarely if ever isolated from the rest of the world; people will incorporate and reinterpret aspects of western knowledge and practice into their traditions as part of the ongoing process of globalization. The nature of indigenous knowledge changes when it is taken from its local cultural context and enters into the discourse of scientists, political decision makers and development workers, needs to be considered.

According to key donors such as the World Bank, social capital, like indigenous knowledge has important implications for development theory, practice and policy. Donor organizations can rarely directly intervene in the local-level processes of social capital accumulation and also decay. They can influence, however, the broader policy environments under which development projects and programs are designed and implemented, in ways that can either facilitate or obstruct processes of pro-poor social capital accumulation. As the world's largest intergovernmental organization concerned with poverty alleviation, the World Bank, through its projects, can make or break social capital. Interpretations of social capital vary and those used by the World Bank, may not be in keeping with definitions of social development used by INGOs and grassroots organizations which are often although not always, less market oriented. Social capital is being used in a market-oriented way for commercial purposes which is the theme of next section.

\section{6. 'NOT TO SHARE' - CORPORATE CULTURE: THE INTELLECTUAL PROPERTY DILEMMA}

Social capital can be used as much for commercial purposes as for civic purposes. Commercial interests from the developed world prospect for information available in the unprotected public domain of indigenous societies. Indigenous knowledge, particularly in the areas of biology, medicine and ecology holds great wealth-maximizing potential where indigenous knowledge has become a valuable commodity which can be patented and copyrighted. Indigenous peoples see their knowledge of plants and medicines converted into private property by outsiders and corporations through patenting. Also the digital revolution has dramatically increased the ability of corporations to appropriate and to profit from the cultural knowledge of indigenous peoples, which is largely unprotected by existing intellectual law. 
Case studies have documented the acquisition of native crop varieties for the genetic improvement of seeds, the transformation of traditional herbal medicines into marketable drugs by pharmaceutical companies, the exploitation of indigenous music by record companies. Robert Chambers has warned of the danger of " mining of indigenous knowledge. Future projections based upon current trends indicate the demise of social capital of certain indigenous groups, their traditional knowledge, and entire way of life (Norchi, 2000).

In this section, I will discuss the appropriation of indigenous knowledge for commercial purposes and reflect on the conflict of a strong public purpose interest in greater community access to indigenous knowledge-derived products (especially pharmaceuticals) versus the need for the implementation of mechanisms for the compensation of indigenous peoples for commercial use of their knowledge. Within this conflict, I will discuss the transfer of indigenous knowledge into 'scientific' knowledge. I will refer to the 'mining' of indigenous knowledge from a group of indigenous people, the 'Onge'.

Much of the indigenous knowledge appropriated for commercial interests is for scientific / medical purposes. As indigenous knowledge is the result of a continuous process of experimentation, innovation, and adaptation it blends with science and technology. However, once indigenous knowledge is drawn within the boundaries of science it is difficult to know where to draw the boundaries between it and science. Not only has indigenous knowledge been grossly undervalued by western-trained 'scientific' managers in terms of its potential practical applications, it has also been seen as curiously insufficiently 'real' to merit any certain legal status or protection from patents and copyrights which give value and ownership to western scholarly knowledge and expertise. The World Conference on Science (NUFFIC, 2002) acknowledged the relevance of indigenous knowledge and recommended that scientific and traditional knowledge should be integrated in interdisciplinary projects.

When indigenous knowledge is transferred into 'scientific knowledge', the delicate issue of intellectual property rights is to be addressed. Indigenous intellectual property rights are currently the focus of an international lively debate - a profound shift in the way indigenous knowledge is conceptualized and contextualized is underway (Brown, 1998). The assumptions that inform this emerging perspective are: 1) an ethnic nation - a people can be said to have enduring, comprehensive rights in its own cultural production and ideas. 2) a groups' relationship to its cultural productions constitutes a form of ownership 3) cultural information that was gathered in the past by anthropologists, missionaries, government administrators, novelists is by definition so contaminated by the realities of colonial power that it cannot meet the standards of informed consent. This information may therefore be subjected to severe access restrictions when and if its subjects deem its presence in the public domain.

I shall now give one example of how indigenous knowledge is being used for commercial purposes and how the the social capital of one particular group of indigenous people, the 'Onge' people are facing a demise in their social capital, as pharmaceutical companies are trying to patent some of their indigenous knowledge, as recorded by Norchi (2000). The Onge are a traditional group who live on the island of Little Andaman in the Indian ruled Andaman and Nicobars. The Onge social organization includes a substantial reservoir of social capital and in all of their activities the Onge function as small scale and cohesive social organizations. The 
Onge have developed expectations and demands pertaining to ownership e.g they have long engaged in trade in the form of gift or exchange, an Onge person owns what $\mathrm{s} / \mathrm{he}$ catches or gathers, it becomes private property - however private property is pursued and used for the common good of the social group; it is valued to the extent it fulfills the well-being of the social group. Norchi argues that the Onge's cooperation for a group purpose now risks being displaced by the application of new intellectual property policies motivated by external elite demands.

The Onge are attracting a lot of interest because they possess a considerable store of indigenous knowledge about medicinally-relevant plant species. Until recently, this indigenous knowledge was unknown to outside communities, now teams from international drug companies have been examining the pharmaceutical treasure chest that is in the Andaman tropical forest. Onge have specific knowledge of a plant which is very effective against a parasite which causes malaria (the Onge are the only people in the Andaman and Nicobars islands that do not suffer from malaria). Scientists are working to isolate the actively biotic ingredient of the plant, and there is a race to claim a patent. Pharmaceutical companies have expressed an interest in entering into an arrangement with whoever is granted a valid patent and have offered payment to individual Onge tribesmen to serve as their exclusive informants. It is the filing of patent applications based upon indigenous knowledge accompanied by increased access to Little Andaman Island, that presents grave danger for the Onge and is adding to the ecological squeeze that they now face.

This is just one example as documented by Norchi (2000) of the appropriation of indigenous knowledge by a multinational corporation for profit. A number of initiatives are being explored to try and protect indigenous knowledge from exploitation in the market-place. Legal scholars, anthropologists and native scholars are now proposing new legal regimes designed to defend indigenous cultures by radically expanding the norm of copyright and proposals that indigenous people should be able to copyright their ideas (Brown, 1998). The US Patent and Trademark Office is studying a variety of issues surrounding trademark protection for the official insignia of federally and / or State recognized Native American Tribes.

In order to address the issue of intellectual property rights, the Center For Indigenous knowledge for Agriculture and Rural Development (CIKARD) has been closely involved with a growing global network of indigenous - knowledge resource centers - these centers provide the mechanisms for protecting indigenous knowledge when that is in the best interest of the community of discovery and the country (Stone, 1998). International initiatives such as the WIPO (World Intellectual Property Organization) net are set to serve as a powerful tool to aid examiners in patent and trademark offices across the world to assess the state of current traditional knowledge. Attempts to introduce such measures are encouraging signs that some attention is being given to mechanisms for the compensation of indigenous peoples for the commercial use of their knowledge.

\section{CONCLUSION}

Indigenous knowledge is being shared on the local, national and global scale. Does this knowledge need to flow and be shared in all directions, from South to North, from rural to urban, from developing to developed? To share or not to share; that is the question? While development 
agencies are aiding the development of national and global indigenous knowledge networks, I would argue that they are failing to take into account the contextualized nature of indigenous knowledge and the problems associated with transferring and sharing indigenous knowledge outside of the community from where it arose. I believe that development agencies should be putting more of their resources into systems of sharing indigenous knowledge on a local scale and harnessing the indigenous knowledge embedded in local practices, relationships, and rituals in order to provide powerful problem-solving strategies for local communities

Governments, donor agencies, NGOs, corporations along with communities need to create operative frameworks, for intellectual property rights, to engender respect for indigenous knowledge. Legislative mechanisms need to be developed that impose new limits on the sharing of information in the name of protecting indigenous peoples.

\section{REFERENCES}

Agrawal, Arun (1995). Indigenous and Scientific Knowledge: Some Critical Comments. Indigenous Monitor, 3(3) [http://www.nuffic.nl/ciran/ikdm/3-3/articles/agrawal.html]. Accessed 05/02.

Bourdieu, P. (1986). "The Forms of Capital." In Handbook of Theory and Research for the Sociology of Education. New York: Greenwood Press.

Briggs, Xavier de Souza. (1998). "Brown Kids in White Suburbs: Housing Mobility and the Multiple Faces of Social capital" Housing Policy Debate 9 (1).

Brokensha, D.M., M.Warren and Oswald Werner (eds.). (1980). Indigenous Knowledge Systems and Development .Washington D.C.:University Press of America.

Brouwer, Jan. (1993). "Indigenous Knowledge: The Proof Is In The Eating of the Pudding". Indigenous Knowledge and Development Monitor [http:/www.nuffic.nl/ciran/ikdm/63/reaction.html]. Accessed 04/12/02.

Brown, Michael F. (1998). Can Culture Be Copyrighted? Current Anthropology 39.2 193-219.

Ellen, Roy and Holly Harris. (1996). Concepts and Indigenous Environmental Knowledge in Scientific and Development Studies Literature: A Critical Assessment.East-West Environmental Linkages Network Workshop 3, Canterbury 8-20 May 1996.

Flavier, J.M et al. (1995). "The Regional Program for the Promotion of Indigenous Knowledge in Asia". In The Cultural Dimension of Development:Indigenous Knowledge Systems. Edited by D.Michael Warren, D.M., L.J. Slikkerveer, D. Brokensha. London: Intermediate Technology Publications.

Ganguli, Prabuddha. (2000). Intellectual Property Rights: Mothering Innovations to Markets. World Patent Information, 22: 43-52.

Ganguli, Prabuddha. (1999). Intellectual Property Rights In Transition. World Patent Information, 20 (3-4): 171.

Gorjestani, N Cultural Diversity in the $21^{\text {st }}$ Century: The Role of Indigenous Knowledge in Development - World Bank Global Knowledge Fair, Kuala Lumpur, 7-10 March, 2000.

Grenier, Louise. (1998). Working with Indigenous Knowledge: A Guide for Researchers.Ottawa: IDRC 1998.

Kilby, Paul. (2002). Social Capital and Civil Society. [http://www.fdc.org.au/files/pk-sc-cs.pdf]. Accessed 02/04/02. 
McCall, Michael. (1997). Indigenous Knowledge Systems as the Basis for Participation: East African Potentials. Working paper No.36. Enschede: Twente Technological University.

National Research Council.(1992). Conserving Biodiversity: A Research Agenda for Developing Agencies. Washington, D.C.: National Academy Press.

Norchi, Charles H. (2000). Indigenous Knowledge as Intellectual Property. Policy Studies, 33: 158-172.

NUFFIC. (2002). Netherlands Organization for International Cooperation in Higher Education. [http://www.nuffic.nl/ik-pages/about-ik.html]. Accessed 05/02/02.

Portes, Alejandro (ed.). (1998)."Social Capital: Its Origins and Applications in Contemporary Sociology" Annual Review of Sociology, 4:1-24.

Posey, Darrell A., and Graham Dutfield. (1996). Beyond Intellectual Proprty: Toward Traditional Resource Rights for Indigenous Peoples and Local Communities. Ottawa:International Development Research Centre.

Putnam, R. (1993). Making Democracy Work: Civic Traditions in Modern Italy. Princeton University Press.

Silitoe, Paul. (1998). The Development of Indigenous Knowledge.Current Anthropology, 39 (2):223-256.

Stone (1998) [http://www.iitap,iastate.edu/cikard/cikard.html]. Accessed 05/04/02.

UNESCO (2002) Best Practices on Indigenous Knowledge. [http://www.unesco.org/most/bpindi.]. Accessed 04/23/02.

Warren, D. Michael. (1989). The Impact of Nineteenth Century Social Science in Establishing Negative Values and Attitudes Towards Indigenous Knowledge Systems. In Indigenous Knowledge Systems: Implications for Agriculture and International Development. Edited by D. Michael Warren, L. Jan Slikkerveer, and S. Oguntunji

Warren, D.Michael..(1991). Using Indigenous Knowledge in Agricultural Development. World Bank Discussion Paper 127.

Warren, D. Michael, L.Jan Slikkerveer and David Brokensha. (1995). The Cultural Dimension of Development; Indigenous Knowledge Systems. London: Intermediate Technology Publications.

Woolcock, Michael. and Deepa Narayan. (2000). Social Capital: Implications for Development Theory, Research, and Policy. World Bank Research Observer, 15 (2):225-249.

World Bank (2002) Indigenous Knowledge for Development [http://www.worldbank.org/afr/ik]. Accessed 04/23/02. 